${ }^{\circledR}$ Entomologica Fennica. 27 August 1998

\title{
Host acceptance and larval development of the gall midge Dasineura tetensi (Diptera, Cecidomyiidae) on resistant and susceptible black currant
}

\author{
Sven Hellqvist \& Stig Larsson
}

Hellqvist, S. \& Larsson, S. 1998: Host acceptance and larval development of the gall midge Dasineura tetensi (Diptera, Cecidomyiidae) on resistant and susceptible black currant. - Entomol. Fennica 9: 95-102.

The gall midge Dasineura tetensi is a widespread pest of cultivated black currant. Females oviposit on shoot apices, and larvae form galls on leaves which then fail to expand normally. Genetically based resistance to the midge is known to occur among black currant genotypes. In the present laboratory study, larval performance on a susceptible black currant genotype (cv. "Öjebyn") was compared with that on a resistant (cv. "Storklas") genotype and oviposition preferences were investigated. On the susceptible genotype, infested leaves were consistently galled, and larvae developed successfully. On the resistant genotype, there was considerable variation in larval performance, ranging from no development to successful, but slow, development. This variation in expression of resistance occurred also in the field. Leaves of the resistant genotype that were infested with larvae that grew were not as densely galled as corresponding leaves of the susceptible genotype. Individual females offered the two black currant genotypes in sequence, did not show any tendency to discriminate against the resistant genotype.

Sven Hellqvist, Department of Agricultural Research for Northern Sweden, Section for Plant Protection, Swedish University of Agricultural Sciences, Box 4097, S-904 03 Umeå, Sweden.e-mail: Sven.Hellqvist@njv.slu.se Stig Larsson, Department of Entomology, Swedish University of Agricultural Sciences, Box 7044, S-75007 Uppsala, Sweden.e-mail: Stig.Larsson@entom.slu.se

Received 19 June 1996, accepted 10 February 1998

\section{Introduction}

The relationship between female host plant preference and offspring performance has been a central issue in theories on plant-insect interactions (Thompson 1988, Courtney \& Kibota 1990, Jaenike 1990). The basic assumption has been that degree of preference should be positively corre- lated with juvenile performance. However, observed relationships range from good to poor (Thompson 1988), and several explanations for poor preference/performance correlations have been proposed (Thompson 1988, Fox \& Lalonde 1993, Larsson \& Ekbom 1995). Since gall-forming insects have such an intimate relationship with their host plants, they should be especially sensi- 
tive to variation in host quality (Mattson et al. 1987, Larsson \& Ekbom 1995). Thus, one should expect a strong correlation between preference and performance.

Most earlier studies of preference/performance relationships in galling insects have focused on within-plant comparisons, e.g. shoot size (Price et al. 1987, Craig et al. 1989, Burstein \& Wool 1993) and leaf size (Whitham 1983) and in most of these cases a good correspondence between preference and performance has been demonstrated. However, few studies are available where conspecific host genotypes have been compared. Anderson et al. (1989) showed that the tephritid Eurosta solidaginis performed better on preferred plants, whereas no correlation between preference and performance was found for either of two cecidomyiids, Dasineura marginemtorquens (Larsson \& Strong 1992, Larsson et al. 1995) and Mayetiola destructor (Morril 1982).

The black currant leaf midge, Dasineura tetensi (Rübs.) (Diptera; Cecidomyiidae), is a monophagous gall midge, with black currant, Ribes nigrum L., as its only natural host (Barnes 1948, Keep 1985). It has long been known that black currant genotypes differ in their susceptibility to gall midge attack. The rather small differences in susceptibility found in early studies were attributed to differences among black currant genotypes in terms of the length of their growth period (Greenslade 1941) or to the oviposition preferences of female midges (Stenseth 1966). Keep (1985) discovered that among genotypes from northern Scandinavia and Russia a few showed no symptoms of attack, whereas most genotypes showed severe symptoms. Although it was shown that the resistance was under strong genetic control, no other aspects concerning the nature of resistance in these genotypes was investigated.

$D$. tetensi is distributed throughout areas where black currant is grown in Europe and Siberia. Adult midges live for only a few days at most. Females oviposit on minute leaves at the shoot apices, and first-instar larvae move to the upper side of expanding leaves upon hatching. Infested leaves fail to expand normally and become crumpled and twisted, the resulting "gall" being simple in structure with no definite form or size. The larvae feed on plant sap that exudes through the leaf epidermis. Feeding eventually leads to leaf necrosis, with the size of the necrotic area varying, depending on shoot vigour and larval density. When full-grown, third-instar larvae leave the gall to pupate in the soil. There are 2-4 generations each year (e.g. Greenslade 1941, Stenseth 1966).

Observations in experimental fields (reported here) and commercial black currant cultivations, as well as data from preliminary greenhouse experiments, confirmed the finding that "Sunderbyn II", one of the genotypes reported as resistant by Keep (1985), as well as some of its progenies, show resistance to $D$. tetensi. Galls usually fail to develop or develop poorly, on the resistant genotypes. In the present experimental study, we first compared a resistant and a susceptible genotype in an oviposition acceptance test with $D$. tetensi females. We then compared larval performance on the same two genotypes.

\section{Material and methods}

\subsection{Midge infestation in the field}

Symptoms of gall midge infestation were assessed in two separate experimental fields (situated about $1 \mathrm{~km}$ apart) with black currant in Umeå, northern Sweden $\left(63^{\circ} 45^{\prime} \mathrm{N}\right.$, $20^{\circ} 15 \mathrm{E}$ ). In both fields, several different genotypes (varieties or breeding lines) were grown, five of them common to both. In both fields the respective genotypes were planted in plots ( 49 plants/plot in Field 1, 6 plants/plot in Field 2) in randomized block design with four blocks (some genotypes in Field 1 were only planted in one of the blocks). Midge infestation was graded on a 0-6 scale. Grade 0 indicated nil leaf symptoms and Grade 6 indicated very severe infestation, with all shoots having several completely distorted leaves. Grades 0 to 6 represent roughly an average reduction in functional leaf units per shoot, due to midge attack, of $0 ; 0.025 ; 0.25 ; 0.75 ; 1.5 ; 3$ and 5 respectively. Assessments were done on vigorous long shoots in late August 1996 (symptoms from the second midge generation of the year) and in late July 1997 (symptoms from the first generation).

\subsection{Experimental studies}

\subsubsection{Insect material}

D. tetensi used for the experiments originated from a black currant plantation in northern Sweden $\left(63^{\circ} 45^{\prime} \mathrm{N}, 19^{\circ} 30^{\prime} \mathrm{E}\right)$. Insects were cultured for several generations on black currant in the greenhouse. Midges used in the experiments 
emerged from pupae during the night or morning and were no more than 15 hours old at the time of their use in the experiments.

\subsubsection{Plant material}

Black currant plants used in the experiments were grown from stem cuttings $5-7 \mathrm{~cm}$ long. After rooting, they were planted in $12-\mathrm{cm}$ pots in peat substrate and were fertilized weekly. All plants were in their active growth phase. The varieties "Öjebyn" and "Storklas" were chosen as representatives of a susceptible and a resistant host genotype, respectively. "Öjebyn" originated in northern Sweden and is now widely planted in black currant plantations throughout northem Europe. This variety was ranked as highly susceptible to D. tetensi in the study by Keep (1985). The variety "Storklas" is a new Swedish variety, which derives its gall midge resistance from its parent "Sunderbyn II", which was found to be among the most resistant genotypes by Keep (1985). "Storklas" was used instead of "Sunderbyn II" because its morphology and growth rate more closely resemble that of "Öjebyn".

\subsubsection{Host acceptance}

Experiments to test whether ovipositing females discriminate between the resistant and the susceptible genotype were performed in transparent, cylindrical cages $(16 \times 31 \mathrm{~cm})$ in the greenhouse. The susceptible and the resistant genotype were offered to individual females in sequence. One female, supplied with at least one male, was released in a cage with a potted, single-shooted plant (15-20 cm high). After $3 \mathrm{~h}$, the plant was replaced with an equally sized plant of the other genotype, which was then then offered to the same female for another $3 \mathrm{~h}$. At the end of the experiment, numbers of eggs on the two plants were counted, as well as eggs remaining in the ovary of the female. There were 24 replicates; in six of these, females did not lay any eggs. These replicates, which may represent unmated females, were not included in the data analysis. Among the remaining 18 replicates, the susceptible genotype was offered to the females first in nine trials, and the resistant genotype was offered first in the other nine.

To study female preference, we chose to run an acceptance test, with the two genotypes offered in sequence, instead of conducting the more commonly used choice tests, with both genotypes offered at the same time. We believe that host acceptance is the ecologically relevant parameter (cf. Courtney \& Chen 1988) because a female midge that encounters a black currant plant has to decide whether to accept it for oviposition or reject it. In natural stands, the distribution of black currant bushes is scattered, usually with several meters to the nearest conspecific neighbour. Thus, there is usually no opportunity to "choose" between different, closely located genotypes.

\subsubsection{Larval performance}

Growth of newly hatched larvae was studied on potted black currant plants in the greenhouse. About five female $D$. tetensi were allowed to oviposit for $1.5 \mathrm{~h}$ on either resistant or susceptible plants placed individually in transparent cages. Plants were then kept under continuous light and at a temperature between 21 and $27^{\circ}$ (reached on sunny days). Six to ten laryae were sampled for body length measurements, from each of two plants of each genotype every $12 \mathrm{~h}$, from 72 until $168 \mathrm{~h}$ after oviposition.

\section{Results}

\subsection{Midge infestation in the field}

Most genotypes were highly susceptible to $D$. tetensi and showed consistently severe symptoms (Grade 4 or higher; Table 1). On these genotypes, almost all long and vigorous shoots showed symptoms, with several galled leaves. At least some of the galled leaves were completely distorted. Two genotypes, "Sunderbyn II" and "5/73-67" ("Sunderbyn II" $\times$ "Öjebyn"), only grown in Field 1, were highly resistant and almost symptomless in both years. In case galls were seen, they were restricted to only a minor part of a leaf. "Ben Sarek" showed in both fields and both years an intermediate resistance. Midge symptoms were seen on a

Table 1. Assessment of symptoms of infestation by $D$. tetensi on black currant varieties and breeding lines, in two separate fields in Umeå, northern Sweden. Grading on a 0-6 scale (Grade $0=$ nil symptoms, $6=$ very severe symptoms). ${ }^{*}=$ assessment of one plot only, else range of grades from four plots.

\begin{tabular}{|c|c|c|c|c|}
\hline \multirow[t]{2}{*}{ Genotype } & \multicolumn{2}{|c|}{$\begin{array}{c}1996 \\
\text { (2nd generation) }\end{array}$} & \multicolumn{2}{|c|}{$\begin{array}{c}1997 \\
\text { (1st generation) }\end{array}$} \\
\hline & Field 1 & Field 2 & Field 1 & Field 2 \\
\hline Ben Sarek & $2-3$ & $3-4$ & $2-3$ & $2-3$ \\
\hline Storklas & 1 & $3-4$ & $0-1$ & $1-2$ \\
\hline Nikkala XI & $6 *$ & $5-6$ & $5 *$ & $5-6$ \\
\hline 7801-31 & 6 * & 6 & $5 *$ & $4-5$ \\
\hline $74020-8$ & $5-6$ & $5-6$ & $4-5$ & $4-6$ \\
\hline $5 / 73-67$ & $0-1$ & - & 0 & - \\
\hline Öjebyn & - & $5-6$ & - & $4-5$ \\
\hline Hildur & $4-6$ & - & $4-5$ & - \\
\hline $1 / 68-5$ & $4-5$ & - & $4-5$ & - \\
\hline Sunderbyn II & 1 * & - & $0^{*}$ & - \\
\hline Matkakoski & $5 *$ & - & $4^{*}$ & - \\
\hline
\end{tabular}




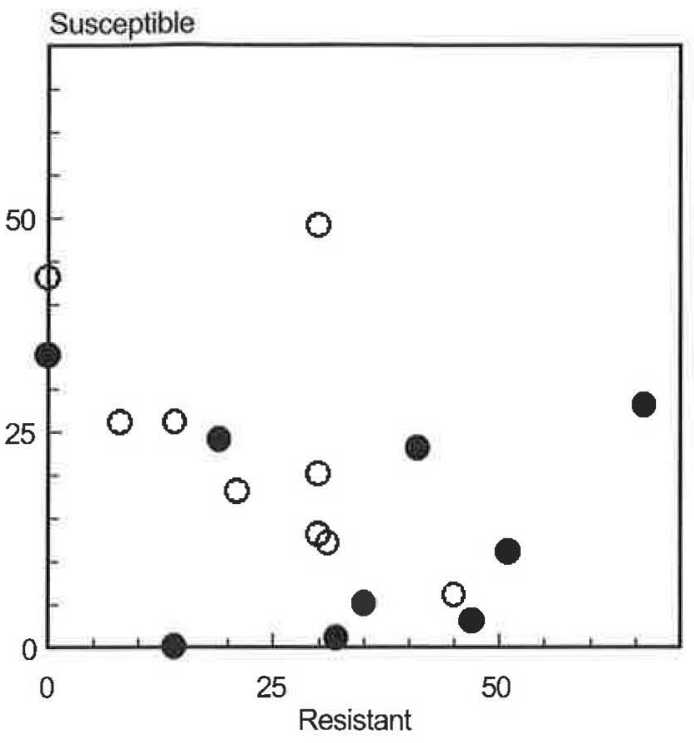

Fig. 1. Number of eggs laid by Dasineura tetensi on susceptible (cv. "Öjebyn") and resistant (cv. "Storklas") black currant in host acceptance test. Each symbol represents one female. Filled ring, resistant genotype offered first; open ring, susceptible genotype offered first.

high proportion of the shoots, but the galls rarely affected whole leaves. "Storklas" was different from the other genotypes in being almost symptomless in both years in Field 1, but showing rather strong symptoms in Field 2, especially in 1996 when the symptoms were as strong as in "Ben Sarek".

\subsection{Host acceptance}

There was large variation among individual females concerning the distribution of their eggs among the two plant genotypes (Table 2, Fig. 1). Fifteen out of 18 females laid eggs on both geno- types. More eggs were laid on the resistant genotype $(\bar{x}=28.6, \mathrm{SD}=17.8)$ than on the susceptible one $(\bar{x}=19.0, \mathrm{SD}=14.1)$, but the difference was not significant (Wilcoxon paired sample test: $P=$ $0.157, T=53, n=18$ ).

On average, individual females laid a total of $47.6(\mathrm{SD}=18.2)$ eggs, which corresponded to $77.6 \%$ ( $\mathrm{SD}=20.1$ ) of their total egg supply. More eggs $(\bar{x}=63.9 \%, \mathrm{SD}=29.0)$ were laid on the plant offered during the first period. The total egg supply was never totally depleted after the first ovipositional period, but in five cases no more than one egg remained in the female ovary after the second period.

On average during the first period, females confined to the resistant genotype oviposited $49.8 \%$ ( $\mathrm{SD}=21.8$ ) of their total egg-supply, whereas those confined to the susceptible genotype laid $42.6 \%,(\mathrm{SD}=16.3)$ of their eggs (MannWhitney test, $P=0.211, U=49, n=8,9)$. During the second period, females on the resistant genotype laid on average $62.9 \%$ ( $\mathrm{SD}=34.0)$ of the remaining eggs while the corresponding value for the susceptible genotype was $48.6 \%(\mathrm{SD}=44.8)$ (Mann-Whitney test: $P=0.596, U=41.5, n=8$, $9)$. The differences were not significant.

\subsection{Larval performance}

There were large differences in larval growth between the two genotypes of black currant. Eggs hatched on both resistant and susceptible plants on the third day after oviposition. On the susceptible genotype, infested leaves were successfully galled. Larvae reached their third (final) instar about $130 \mathrm{~h}$ after oviposition and left the plant full-grown to pupate in the soil about two days later. On the resistant genotype there was considerable variation in larval performance. In some replicates, larvae did not increase in size and re-

Table 2. Oviposition by individual female $D$. tetensi on resistant (cv. "Storklas") versus susceptible (cv. "Öjebyn") black currant genotypes, offered in sequence in host acceptance test. Means (eggs/plant) \pm SD, $(n)$.

\begin{tabular}{|c|c|c|c|}
\hline \multirow{2}{*}{$\begin{array}{l}\text { Genotype } \\
\text { offered first }\end{array}$} & \multicolumn{2}{|c|}{ Black currant genotype eggs laid on } & \multirow{2}{*}{$\begin{array}{l}\text { Remaining eggs } \\
\text { after oviposition }\end{array}$} \\
\hline & Susceptible & Resistant & \\
\hline Susceptible & $23.7 \pm 14.3(9)$ & $23.2 \pm 13.8(9)$ & $14.9 \pm 14.5(8)$ \\
\hline Resistant & $14.3 \pm 13.0$ & $33.9 \pm 20.4(9)$ & $17.0 \pm 23.1$ \\
\hline
\end{tabular}


Fig. 2. Lanal growth of Dasineura tetensi on susceptible (cv. "Öjebyn") and resistant (cv. "Storklas") black currant. Each symbol represents the mean value of 6-10 larvae on one plant. All values are independent, i.e. refer to larvae on different plants.

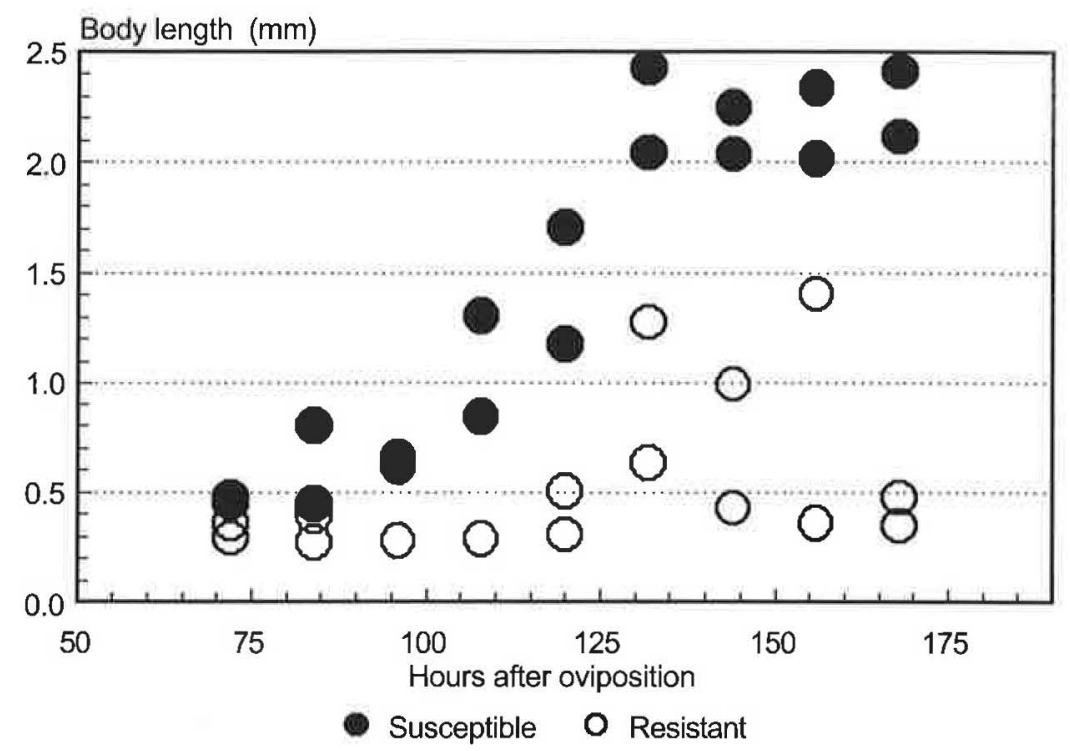

mained in their first instar until they died. However, mortality was difficult to document because eggs could not be counted without destroying the leaf, and dead first-instar larvae were very difficult to recover at the end of the experiment. Larvae did grow on other replicates, although much more slowly than on the susceptible genotype (Fig. 2). Infested leaves with larvae that died in the first instar were not galled but became faintly discoloured. Leaves with larvae that grew were galled to some extent, but the leaves were not as densely wrinkled and twisted as on the susceptible genotype, the larvae thus being more exposed to the elements and natural enemies than on the susceptible genotype.

\section{Discussion}

This study provides evidence for large variability in the susceptibility of conspecific plant genotypes to a herbivorous insect. Four of the genotypes that were assessed for midge infestation in the field, were also included in the study by Keep (1985) in Scotland. "Sunderbyn II" showed almost no signs of gall midge infestation in either place, while the genotypes "Öjebyn", "Nikkala XI" and "Matkakoski" were found to be highly susceptible to $D$. tetensi in both studies. This indicates that the resistance in "Sunderbyn II" is not just a local phenomenon due to aberrant midge genotypes. For the experiments we chose to study "Storklas" instead of "Sunderbyn II". Minor studies of "Sunderbyn II" in the greenhouse have, however, shown that the gall midge responds to it in a similar way as to "Storklas", i.e. no ovipositional discrimination and high first larval instar mortality.

On the resistant black currant genotype "Storklas", galling was weak or non-existent, and many D. tetensi larvae died before moulting to the second instar in the larval performance experiment. By contrast, on the susceptible genotype proper galls were consistently formed, and larvae developed to the adult stage. Similar patterns of resistance have been reported for two other species of cecidomyiids, Dasineura marginemtorquens on the willow Salix viminalis (Larsson \& Strong 1992, Larsson et al. 1995) and the Hessian fly (Mayetiola destructor) on wheat (e.g. Shukle et al. 1990). Larvae of these cecidomyiids die within a few days after hatching on resistant plant genotypes.

The mechanism of resistance to $D$. tetensi is unknown, as are the mechanisms of feeding and gall initiation on susceptible $R$. nigrum. In wheat, neither morphological characteristics nor nutrient deficiencies or toxins seem to be important factors contributing to the resistance against M. destructor (Shukle et al. 1990). Instead, there is some evidence supporting the hypothesis that 
hypersensitivity is the basis of resistance (Shukle et al. 1992). In D. marginemtorquens, much less is known about what causes resistance in $S$. viminalis. No obvious morphological differences appear to exist between susceptible and resistant $S$. viminalis, and no typical hypersensitivity reactions have been observed in resistant genotypes (Larsson \& Strong 1992, Glynn \& Larsson 1994, Larsson et al. 1995, S. Larsson, C. Glynn \& S. Höglund unpubl.).

Resistance against $D$. tetensi in the variety "Storklas" seems to be unstable; larval performance in this experiment ranged from $100 \%$ mortality to successful, but slow, development. Similarly, in the assessments of field infestation, "Storklas" showed almost no symptoms of galling in one field but a rather high degree of galling in the other, despite similar infestation levels on susceptible genotypes in neighbouring plots in both fields. In earlier greenhouse experiments there was consistently $100 \%$ mortality on "Storklas" as well as on related resistant genotypes. We do not believe that the lower resistance found in the laboratory experiment reported here was due to the midge genotypes used being more virulent. Midges in this and previous experiments were of the same origin and had been cultured on susceptible genotypes only. The expression of resistance may, instead, be influenced by plant vigour (cf. Price 1991) or direct abiotic factors such as temperature (cf. Sosa \& Foster 1976) or humidity. Small differences in vigour, temperature and/or humidity in the greenhouse and in the field could have interacted with the resistance factor.

In our acceptance experiment, females laid a high proportion of their eggs on a genotype on which most of the resulting larvae died. In 16 out of 18 replicates, the female accepted the resistant genotype, and in 12 replicates more eggs were laid on the resistant genotype than on the susceptible one. Host acceptance may be influenced by egg load; i.e. ovipositing females may be less discriminative when having many eggs in their abdomen compared with situations where they carry fewer eggs (e.g. Harris \& Miller 1988, Courtney et al. 1989). If this had been the case, females should have been choosier during the second ovipositional period, by which time they had already deposited some of their eggs. However, we found no indication of such a change in motiva- tion to oviposit between periods, further supporting the hypothesis that $D$. tetensi females do not discriminate against resistant plants.

Results from this study are in accordance with those reported by Larsson and Strong (1992) and Larsson et al. (1995) on resistance to D. marginemtorquens in $S$. viminalis and by Morril (1982) on resistance to $M$. destructor in wheat. As with black currant, larval mortality on these resistant genotypes was very high; yet females did not discriminate against these genotypes in oviposition choice tests. It is noteworthy that these gall midges respond to resistant genotypes in a very similar way although they each utilize different host plants. We have two possibilities to explain the lack of correspondence between female preference and larval performance. Both are based on the suggestion that females are unable to discriminate against the resistant genotype. First, the association between plant and insect may be new ("time hypothesis" (Thompson 1988)), or second, females may experience "host confusion" (Fox \& Lalonde 1993, Larsson \& Ekbom 1995).

The "time hypothesis" proposes that the insect has simply not had enough time to evolve behaviour whereby it can discriminate against a non-suitable genotype. This explanation was suggested by Larsson and Strong (1992) for the lack of correlation in the $S$. viminalis/D. marginemtorquens system (but cf. Larsson \& Ekbom 1995), and the same explanation may apply to the $D$. tetensi/R. nigrum system as well. $R$. nigrum grows wild in most parts of Sweden (Mossberg et al. 1992), but most southern populations probably represent genotypes that have escaped from cultivation (e.g. Almquist 1965). In the far northern province of Norrbotten, however, there is no doubt that many black currant populations are indigenous. Genotypes from this area are generally photoperiodically adapted to growth at high latitudes and show a large variation in plant characteristics. "Sunderbyn II", the source for gall midge resistance in the resistant genotype used in this study, originated in this region. It is unclear whether $D$. tetensi is also native to Norrbotten. The first record of D. tetensi from central Sweden is from 1947 (Sylvén 1952), whereas in northern Sweden it was, despite earlier surveys of pests on black currant, not recorded until 1992. D. tetensi then appeared in several commercial black cur- 
rant fields and small gardens scattered over a wide area (S. Hellqvist, pers. obs.). These northern midge populations may be of southern origin, perhaps recently spread to the region on imported plant material, in debris on harvesting machines or by wind dispersal. Thus, it is possible that the lack of a correlation between preference and performance for $D$. tetensi reflects a new association of host plant genotype and insect. On the other hand, the possibility that $D$. tetensi has a longer history in northern Sweden is supported by Vappula (1962), who reported the species in North Ostrobothnia in northern Finland, not far from the Swedish border.

According to the "host confusion" hypothesis, the ability of the insects to choose a suitable host may be constrained by their inability to discriminate between plant qualities. Thus, two plant genotypes might be perceived as identical even though they differ in some respect that profoundly influences the insect's performance. In the case of gall midges, we propose that the trait(s) responsible for resistance, which apparently cannot be distinguished by ovipositing females, is an unknown inducible response of the plant triggered by larval feeding, or simply a lack of the compatible plant response. A resistance-trait that does not manifest itself until after the larvae hatch would not be present when the female is deciding where to oviposit. Hence she would not be able to respond to the trait if it is not correlated with other, recognizable plant characteristics. We are not aware of any obvious or consistent differences in leaf morphology between resistant and susceptible black currant genotypes that females could use as ovipositional cues.

Acknowledgements. Thanks are due to Barbara Ekbom, Carolyn Glynn and Christer Björkman for valuable comments on the manuscript.

\section{References}

Almquist, E. 1965: Flora upsaliensis. — Almquist \& Wiksell, Stockholm.

Anderson, S., McCrea, K. D., Abrahamson, W. G. \& Hartzel, L. M. 1989: Host genotype choice by the gallmaker Eurosta solidaginis (Diptera: Tephritidae). - Ecology 70: 1048-1054.

Barnes, H. F. 1948: Gall midges of economic importance. Vol. III: Gall midges of fruits. — Crosby Lockwood \&
Son Ltd. London.

Burstein, M. \& Wool, D. 1993: Gall aphids do not select optimal galling sites (Smynthurodes betae; Pemphigidae). - Ecological Entomology 18: 155-164.

Courtney, S. P. \& Chen, G. K.1988: Genetic and environmental variation in oviposition behaviour in the mycophagous Drosophila suboccidentalis Spcr. - Functional Ecology 2: 521-528.

Courtney, S. P. \& Kibota, T. T. 1990: Mother doesn't know best: selection of hosts by ovipositing insects. - In: Bernays, E. A. (ed.), Insect-Plant Interactions II: 161188. CRC Press, Boca Raton.

Courtney, S. P., Chen, G. K. \& Gardner, A. 1989: A general model for individual host selection. - Oikos 55: 55-65.

Craig, T. P., Itami, J. K. \& Price, P. W. 1989: A strong relationship between oviposition preference and larval performance in a shoot-galling sawfly. - Ecology 70 : 1691-1699.

Fox, C. W. \& Lalonde, R. G. 1993: Host confusion and the evolution of insect diet breadths. - Oikos 67: 577-581.

Glynn, C. \& Larsson, S. 1994: Gall initiation success and fecundity of Dasineura marginemtorquens on variable Salix viminalis host plants. - Entomol. exp. appl. 73: 11-17.

Greenslade, R. M. 1941: The black currant leaf midge Dasyneura tetensi (Rübs.). - Rep. E. Malling Res. Stn for 1940: 66-70.

Harris, M. O. \& Miller, J. R. 1988: Host-acceptance behaviour in an herbivorous fly, Delia antiqua. - J. Insect Physiol. 34: 179-190.

Jaenike, J. 1990: Host specialization in phytophagous insects. - Annual Review of Ecology and Systematics 21: 243-273.

Keep, E. 1985: The black currant leaf curling midge, Dasyneura tetensi Rübs.; its host range, and the inheritance of host resistance. - Euphytica 34: 801-809.

Larsson, S. \& Ekbom, B. 1995: Oviposition mistakes in herbivorous insects: confusion or a step towards a new host plant. - Oikos 72: 155-160.

Larsson, S. \& Strong, D. R. 1992: Oviposition choice and larval survival of Dasineura marginemtorquens (Diptera: Cecidomyiidae) on resistant and susceptible Salix viminalis. - Ecological Entomology 17: 227-232.

Larsson, S., Glynn, C. \& Höglund, S. 1995: High oviposition rate of Dasineura marginemtorquens on Salix viminalis genotypes unsuitable for offspring survival. - Ent. exp. appl. 77: 263-270.

Mattson, W. J., Lawrence, R. K., Haack, R. A. Herms, D. A. \& Charles, P.-J. 1987: Defensive strategies of woody plants against different insect-feeding guilds in relation to plant ecological strategies and intimacy of associations with insects. - In: Mattson, W. J., Levieux, J. \& Bernard-Dagan, C. (eds.), Mechanisms of woody plant defences against insects: $3-38$. Springer. New York.

Morrill, W. L. 1982: Hessian fly: host selection and behavior during oviposition, winter biology, and parasitoids. - 
J. Georgia Entomol. Soc. 17: 156-167.

Mossberg, B., Stenberg, L. \& Ericsson, S. 1992: Den nordiska floran. - Wahlström \& Widstrand. Stockholm. $696 \mathrm{pp}$.

Price, P. W. 1991: The plant vigor hypothesis and herbivore attack. - Oikos 62: 244-251.

Shukle, R. H., Grover, P. B., Jr. \& Foster, J. E. 1990: Feeding of Hessian fly (Diptera: Cecidomyiidae) larvae on resistant and susceptible wheat. - Environ. Entomol. 19: 494-500.

Price, P. W., Roininen, H. \& Tahvainen, J. 1987: Why does the bud-galling sawfly, Euura mucronata, attack long shoots? - Oecologia 74: 1-6.

Shukle, R. H., Grover, P. B. \& Mocelin, G. 1992: Responses of susceptible and resistant wheat associated with Hessian fly (Diptera: Cecidomyiidae) infestation. Environ. Entomol. 21: 845-853.

Sosa, O., Jr. \& Foster, J. E. 1976: Temperature and the expression of resistance in wheat to the Hessian fly. -
Environ, Entomol. 5: 333-336.

Stenseth, C. 1966: Solbærgallmygg (Dasyneura tetensi Rübs.). Undersökelser over biologi, bekjempelse og angrepets betydning for vekst $\mathrm{og}$ avling. - Forsk. Fors. Landbr. 17: 241-258.

Sylvén, E. 1952: Några hortikulturellt anmärkningsvärda gallmyggor. - Statens växtskyddsanstalt. Meddelande N:r 61: 1-12.

Thompson, J. N. 1988: Evolutionary ecology of the relationship between oviposition preference and performance of offspring in phytophagous insects. - Entomol. exp. appl. 47: 3-14.

Vappula, N. A. 1962: Pests of cultivated plants in Finland. - Annales Agriculturae Fenniae 1: 1-239 (Suppl. 1).

Whitham, T. G. 1983: Host manipulation of parasites: Within- plant variation as a defence against rapidly evolving pests. - In: Denno, R. F. \& McClure, M. S. (eds.), Variable plants and herbivores in natural and managed systems: 15-42. Academic Press. 